\title{
Deaths of women of reproductive age: In-depth analysis of data from the Pakistan Demographic and Health Survey 2006-07
}

Pakistan Initiative for Mothers and Newborns (PAIMAN)

Follow this and additional works at: https://knowledgecommons.popcouncil.org/departments_sbsr-rh

Part of the International Public Health Commons, Maternal and Child Health Commons, Social and Behavioral Sciences Commons, and the Women's Health Commons How does access to this work benefit you? Let us know!

\section{Recommended Citation}

Pakistan Initiative for Mothers and Newborns (PAIMAN). 2010. "Deaths of women of reproductive age: Indepth analysis of data from the Pakistan Demographic and Health Survey 2006-07." Islamabad: The PAIMAN Project, JSI Research and Training Institute. 


\section{Deaths of Women of Reproductive Age: In-Depth Analysis of Data from the Pakistan Demographic and Health Survey 2006-07}

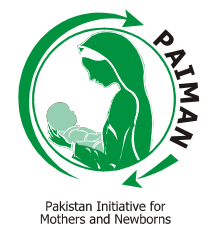





\section{Deaths of Women of Reproductive Age: In-Depth Analysis of Data from the Pakistan Demographic and Health Survey 2006-07}

Psycho-socio-cultural factors contributing to adult female deaths; unpacking indirect maternal deaths and identifying late maternal deaths

Principal Investigator:

Prof. Sadiqua N. Jafarey

Co Investigator: Dr. Azra Ahsan

Reviewers:

Dr. Azra Ahsan Dr. Shireen Bhutta Dr. Sadiah Ahsan Pal Dr. Farah Naz Raza

Statistical Analyst:

Mr. Syed Ejaz Alam 
Copyright (C) 2010 by The PAIMAN Project, JSI Research and Training Institute, Inc.- All Rights Reserved

Any part of this publication may be reproduced or translated by duly acknowledging the source.

The PAIMAN Project is funded by the United States Agency for International Development and implemented by JSI Research \& Training Institute, Inc. in conjunction with Aga Khan University, Contech International, Save the Children, US, The Population Council, and Johns Hopkins University/CCP

This report was prepared by the Population Council, an international, non-profit, nongovernmental organization established in 1952, seeks to improve the well-being and reproductive health of current and future generations around the world and to help achieve a humane, equitable, and sustainable balance between people and resources.

The Council analyzes population issues and trends; conducts research in the reproductive sciences; develops new contraceptives; works with public and private agencies to improve the quality and outreach of family planning and reproductive health services; helps governments design and implement effective population policies; communicates the results of research in the population field to diverse audiences; and helps strengthen professional resources in developing countries through collaborative research and programs, technical exchange, awards, and fellowships.

\section{For inquiries, please contact:}

Population Council

\# 7, Street 62, F-6/3, Islamabad, Pakistan

Tel: 92518445566

Fax: 92512821401

Email: pcpak@popcouncil.org

Web: http://www.popcouncil.org http://www.paiman.org.pk

Published: July 2010

\section{Disclaimer}

"This study/report is made possible by the generous support of the American people through the United States Agency for International Development (USAID). The contents are the responsibility of JSI Research \& Training Institute, Inc and do not necessarily reflect the views of USAID or the United States Government." 


\section{TABLE OF CONTENTS}

Acknowledgments.........................................................................................................ii

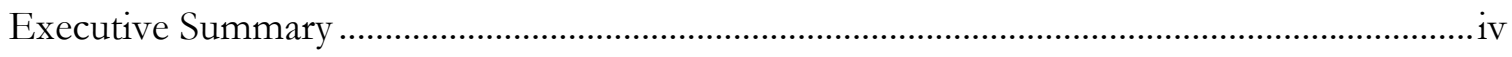

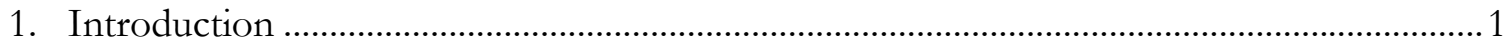

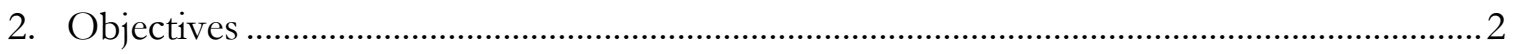

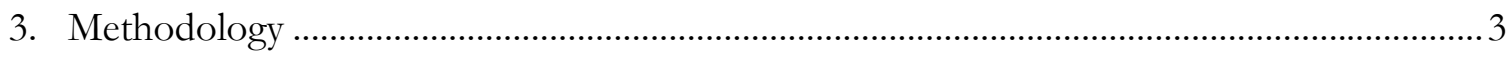

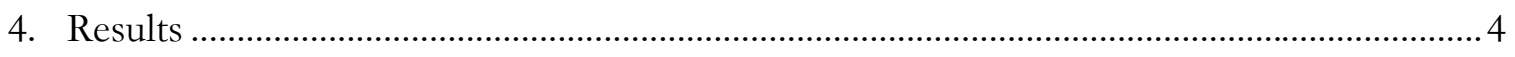

4.1 Sociodemographic Characteristics ........................................................................... 4

4.2 Psycho-Socio-Cultural Factors Contributing to Deaths of Women of

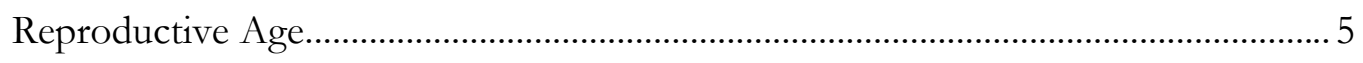

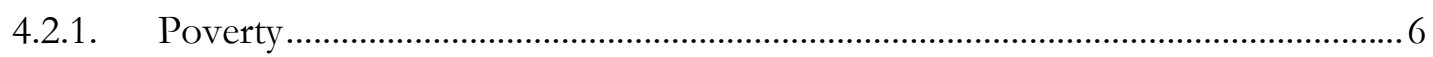

4.2.2. Neglect (and/or Unsupportive Family), Ignorance and Beliefs............................ 8

4.2.3 Supportive Family ……………………………………………………………... 10

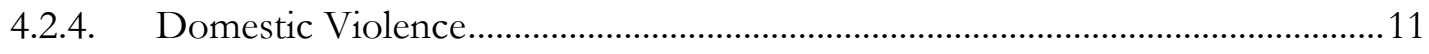

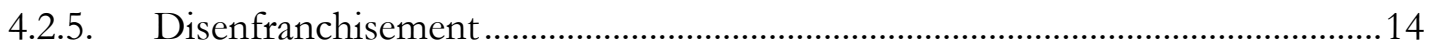

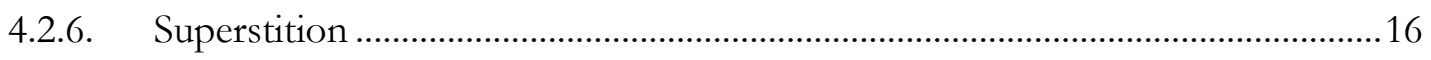

4.2.7. Spiritual/Ritual Treatment...............................................................................19

4.2.8. Low Self-esteem/Helplessness/Depression .........................................................22

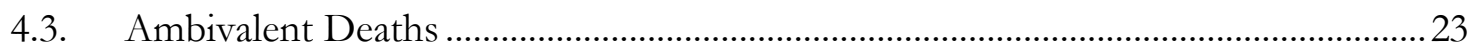

4.4. Maternal Deaths .................................................................................................26

4.4.1. Late Maternal Deaths ...............................................................................................26

4.4.2. Reassessing Category of Maternal Death ..............................................................2

4.4.3. Unpacking Indirect Maternal Deaths .................................................................2

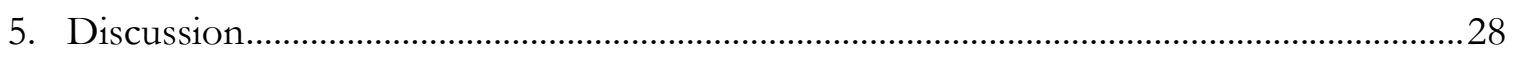

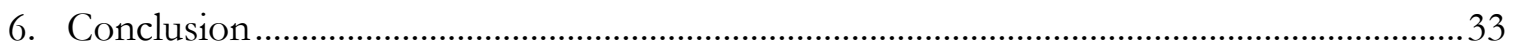

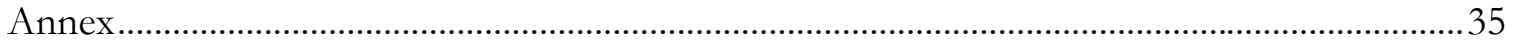

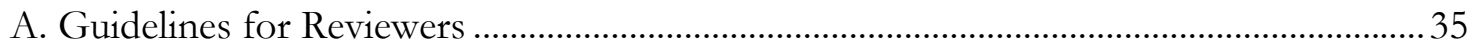




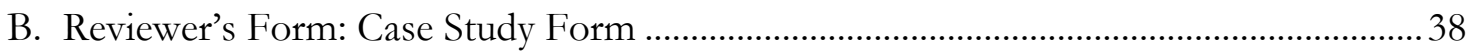

C. Reviewer's Form: Themes Form for Maternal/Adult Female Deaths ............................. 39

D. Reviewer's Form: Unpacking Psycho-Socio-Cultural Factors and Identifying Late Maternal Death, Ambivalent Cases \& Cases Appropriate for Case Study Resulting

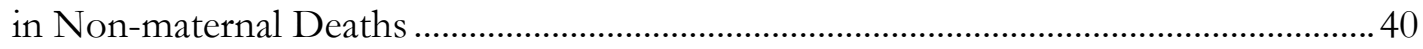

E. Reviewer's Form: Unpacking Psycho-Socio-Cultural Factors and Identify Ambivalent and Interesting Cases Resulting in Maternal Deaths .................................... 4 


\section{ACKNOWLEDGMENTS}

These authors of this report, and the reviewers, had earlier analyzed the medical causes of death among women of reproductive age for the Pakistan Demographic and Health Survey (PDHS) 2006-07 report on verbal autopsies. In sharing insights about the deaths of women of reproductive age with Dr. Zeba Sathar, the importance of further investigation into these deaths was clear. We would like, therefore, to credit Dr. Zeba Sathar, Country Director, Population Council, and Dr. Ali Mir, Director of Programs, Population Council, for providing support, technical and otherwise, for this study.

We would like to acknowledge the support provided by the USAID-funded PAIMAN project, which allowed the project to go forward.

This report would not have been possible without the dedicated and painstaking work of the reviewers. We thank them all: Dr. Azra Ahsan, Dr. Shireen Bhutta, Dr. Sadiah A. Pal and Dr. Farahnaz Raza, who, in spite of their busy schedules, met the deadlines, burning midnight candles to complete their tasks.

Developing the tools for reviewing the verbal autopsy questionnaires was an arduous task. We acknowledge the help of Ms. Iram Kamran and Mr. Mumraiz Khan, both from the Population Council, Dr. Imran Shaikh, from Ziauddin University, and Ms. Shazia Muhammed in developing the review tools.

We also thank Dr. Samiah A. Zia for writing the case studies of the identified verbal autopsies.

Special acknowledgement goes to Dr. Marium Waqas and Dr. Suwaiba Azeem of the National Committee for Maternal and Neonatal Health (NCMNH), for considerable assistance in data entry, data analysis and report compilation, and to Mr. Ejaz Alam of Ziauddin University for statistical analysis.

Final tribute goes to the NCMNH team, especially Mrs. Nighat Saeed Khan, for their patience and facilitation throughout this activity.

\section{Prof. Sadiqua N. Jafarey}

Dr. Azra Ahsan 


\section{EXECUTIVE SUMMARY}

The 2006-07 Pakistan Demographic and Health Survey was carried out to provide a comprehensive status of the health and demographic indicators obtaining in Pakistan. An important aspect of the survey was its ability to measure the maternal mortality ratio for the country and the four provinces. The survey included a three-year recall (2003-06) of all births and deaths in approximately 95,000 sampled households. All female deaths between the ages of 12-49 years were investigated in detail using a verbal autopsy (VA) questionnaire. The questionnaire included details about the woman's characteristics and the symptoms and circumstances prior to her death. A total of 1,085 verbal autopsy questionnaires were reviewed by the National Committee for Maternal and Neonatal Health (NCMNH) by a panel of expert obstetrician/gynecologists and sociologists. During the review process the category of death and the medical causes were assigned and coded according to the World Health Organization International Classification of Disease (ICD-10). This information on maternal deaths was made available in the findings of the PDHS.

The Population Council, a partner of the Pakistan Initiative for Mothers and Newborns project (PAIMAN), was responsible for undertaking operations research and program evaluation commissioned the National Committee on Maternal and Neonatal Health to revisit and conduct an in-depth analysis of the 1,085 verbal autopsies bringing to the fore the rich psycho-social-cultural data collected from the verbatim section of the forms.

The in-depth analysis and report writing was carried out from May 2009 to June 2010. The analysis had the following objectives.

A. Identify psycho-socio-cultural issues present in the lives of the women whose verbal autopsies were reviewed, such as:

- Neglect either due to family decisions, poverty or ignorance

- Domestic violence

- Gender discrimination

- Disenfranchisement

- Superstition, spiritual/ritual treatment,

- Low self-esteem, etc.

Identify ambivalent cases (i.e., when there is conflicting evidence in the verbal autopsy questionnaire as to the category and cause of death)

Identify late maternal deaths

B. Reassess category of maternal death 
C. Unpack the indirect maternal deaths (in greater detail than the ICD-10 coding)

The review yielded important information as to the social determinants of women's deaths in Pakistan.

The major psychological and cultural factors identified with the deaths included poverty, neglect, ignorance, disenfranchisement and a reliance on spiritual treatment. Poverty was the major reason cited by families for not being able to seek timely care.

In the 1,085 verbal autopsies analyzed earlier there was ambivalence as to the cause of death in 10 cases. In these cases the circumstances leading to death as narrated by the respondents in the verbatim section were in conflict with that offered by neighbors or other family members. Upon reassessment it was revealed that the underlying cause in all these deaths was related to either suicide or homicide.

The review has also identified 38 cases of late maternal deaths (i.e., deaths of women from direct or indirect obstetric causes more than 42 days but less than one year after termination of pregnancy). Out of these, 10 were due to direct causes and 28 due to indirect causes.

The review also helped in unpacking the causes of indirect maternal deaths, revealing that hepatic diseases were responsible for the majority of indirect maternal deaths.

Revisiting the Pakistan Demographic and Health Survey has given information that was not captured in the initial analysis. The information obtained highlights the importance of psychological, social and cultural factors in influencing women's lives and wellbeing, as these factors pose an important barrier to seeking appropriate and timely care. 



\section{INTRODUCTION}

The 2006-07 Pakistan Demographic and Health Survey (PDHS) ${ }^{1}$ was undertaken to provide guidance in planning, implementing, monitoring and evaluating health and population programs in Pakistan. This household survey included a 3-year recall (2003-06) of all births and deaths in approximately 95,000 sampled households. All female deaths between the ages of 12-49 years were investigated in detail using a verbal autopsy (VA) questionnaire. The VA questionnaire covered details about each woman's characteristics and the symptoms and circumstances prior to her death. A verbatim account was also recorded so as to help assign a cause of death.

A total of 1,085 verbal autopsy questionnaires were reviewed at the National Committee for Maternal and Neonatal Health (NCMNH) by a panel of expert obstetrician/gynecologists $(\mathrm{OB} / \mathrm{GYN})$ and physicians. During the review process the category of deaths and their medical causes were assigned and coded according to the International Classification of Diseases, version 10 (ICD-10). ${ }^{2}$ Maternal deaths were identified and levels of delay were also assessed. This has been published in the chapter on adult and maternal mortality of the PDHS report.

During the review process, it was felt that a large amount of information regarding psychosocio-cultural factors contributing to the deaths was available in the verbatim section of the VA questionnaires, but this information was not being captured. It was, therefore, decided that the VA questionnaires be revisited with the objective of comprehensively assessing the psycho-socio-cultural factors contributing to the deaths of all adult women and to fill-in the information gaps relating to maternal deaths. Moreover, in some cases among the adult female deaths there was ambivalence as to the cause of death, which needed to be identified and the significance highlighted.

Only those maternal deaths that had occurred up to 40 days after childbirth were included. Women who had died 40 days after childbirth whose cause of death was due to problems that arose during pregnancy and childbirth were categorized as nonmaternal deaths. All of the deaths categorized as late maternal deaths, as per definition by ICD-10 (see text box), needed to be identified and their causes determined.

\footnotetext{
${ }^{1}$ National Institute of Population Studies (NIPS) [Pakistan] and Macro International. 2008. Pakistan Demographic and Health Survey 2006-07. Islamabad, Pakistan: NIPS and Macro International, Inc.

2 World Health Organization. 2007. International Classification of Diseases and Related Health Problems. $10^{\text {th }}$ Revision. Geneva: World Health Organization.
} 
There were some maternal deaths for which it was not possible to identify whether the cause was direct, indirect or coincidental; however, these were included under one of these headings as there was no other category in the reviewer's form. It was felt that these should be listed under a separate heading. The medical causes of indirect maternal deaths had been categorized under a few headings, as per ICD-10 coding. Hence, significant information was masked, e.g., hepatic disease was the leading indirect cause of maternal death but did not emerge as such.

\section{2. ОВJECTIVES}

The objectives of revisiting the verbal autopsy questionnaires were to:

A. Identify psycho-socio-cultural issues present in the lives of the women whose verbal autopsies were reviewed, such as:

- Neglect either due to family decisions, poverty or ignorance

- Domestic violence

- Gender discrimination

- Disenfranchisement

- Superstition, spiritual/ritual treatment

- Low self-esteem, etc.

B. Identify ambivalent cases (i.e., when there is conflicting evidence in the verbal autopsy questionnaire as to the category and cause of death)

C. Identify late maternal deaths

D. Reassess category of maternal death

DEFINITIONS (WHO ICD 10) Maternal Death

The death of a woman while pregnant or within 42 days of termination of pregnancy, irrespective of the duration and site of the pregnancy, from any cause related to or aggravated by the pregnancy or its management but not from accidental or incidental causes.

Maternal deaths are divided into two groups:

Direct Obstetric Death - Death resulting from obstetric complications of the pregnant state (pregnancy, labor and puerperium), from interventions, omissions, incorrect treatment, or from a chain of events resulting from any of the above.

Indirect Obstetric Death - Death resulting from previous existing disease or disease that developed during pregnancy and which was not due to direct obstetric causes, but which was aggravated by physiologic effects of pregnancy.

\section{Coincidental Maternal Death}

Deaths from unrelated causes which happen to occur in pregnancy or the puerperium.

\section{Late Maternal Death}

Death of a woman from direct or indirect obstetric causes more than 42 days but less than one year after termination of pregnancy.

E. Unpack the indirect maternal deaths (in greater detail than the ICD-10 coding) 


\section{METHOdOLOGY}

A review form was developed for this study to capture psycho-socio-cultural factors contributing to maternal deaths (see Annex). A detailed discussion ensued between the reviewers (all OB/GYNs) and sociologists in the process of developing the form.

About 24 randomly selected verbal autopsy questionnaires (12 maternal and 12 nonmaternal deaths) were then reviewed independently by the principal and co investigator (both $\mathrm{OB} / \mathrm{GYNs}$ ) and two sociologists. The objective of the review was to identify psycho-sociocultural themes in the VA questionnaires. The $2 \mathrm{OB} / \mathrm{GYN}$ s then compared the identified themes with each other and, similarly, the 2 sociologists shared notes. These identified themes were then shared between the clinicians and the sociologists. The themes identified by the clinicians and the sociologists were to a great extent similar. The main themes identified included poverty, neglect, ignorance, supportive versus unsupportive family, domestic violence, disenfranchisement, superstition, spiritual/ritual treatment, low selfesteem, etc.

The 1,085 verbal autopsy questionnaires were randomly assigned to the 4 reviewers with a 1 in 4 distribution. All of the reviewers for this study had reviewed the VA questionnaires previously where the category and cause of death were assessed; they were, therefore, familiar with the VA tool.

The cases identified as ambivalent, late maternal or maternal deaths but cause undetermined were discussed at weekly meetings. The 4 reviewers along with the principal investigator and co-investigator (who also functioned as one of the reviewers) then discussed these cases in detail to decide if they indeed belonged to the category identified.

The reviewers were also instructed to identify any other issue present in the verbatim section. When a particular factor was identified it had to be supported by information from the VA questionnaire. If supporting evidence was found, it was documented by entering it in Urdu in the Excel spreadsheet. It was decided not to translate the relevant portion of the verbatim information into English to be sure that information was not lost in translation.

Cases where the respondents ascribed the death to a medical illness (describing the symptoms in great detail) but some other family member or a neighbor reported a different cause of death (mostly violence) were categorized as ambivalent.

Moreover, cases where the information in the verbatim report and the objective data did not match and the interviewers or reviewers felt that certain information was being concealed were also labeled ambivalent. All of these cases were further subcategorized into cases where 
clear evidence of ambivalence existed in the VA questionnaire and others where there was suspicion of ambivalence but concrete evidence was missing.

Deaths that had occurred up to one year after childbirth were recategorized as late maternal deaths (ICD-10). These deaths were further subcategorized into those due to direct cause or indirect cause. Late maternal deaths that were due to coincidental causes were excluded. A new heading of "maternal death but cause undetermined" was included to categorize maternal deaths in which there had originally been difficulty in assigning cause of death. The indirect causes of maternal deaths were further unpacked to see the contribution of each disease causing maternal deaths.

The psycho-socio-cultural themes and other data were entered in Microsoft Excel and were later converted into a format that was configured and applied to the Statistical Package for the Social Sciences (SPSS 17.0).

\section{RESULTS}

Table 1 shows the number and percent distribution of the 1,085 verbal autopsies according to the category of death assigned to them by the reviewers.

Table 1. Number and percent distribution of deaths (verbal autopsies) of women 12-49, from 1,085 verbal autopsies, according to category of death

\begin{tabular}{lrrr} 
& & \multicolumn{2}{c}{ Percent } \\
\cline { 3 - 4 } Category & Number & $\begin{array}{r}\text { Percent of total } \\
\text { verbal autopsies }\end{array}$ & $\begin{array}{r}\text { Percent of maternal } \\
\text { deaths }\end{array}$ \\
\hline Nonmaternal deaths & $\mathbf{7 8 7}$ & $\mathbf{7 2 . 5}$ & na \\
Maternal deaths & $\mathbf{2 9 3}$ & $\mathbf{2 7 . 0}$ & $\mathbf{1 0 0 . 0}$ \\
$\quad$ Direct & 191 & 17.6 & 65.2 \\
Indirect & 49 & 4.5 & 16.7 \\
Coincidental & 12 & 1.1 & 4.1 \\
Maternal but cause not determined & 3 & 0.3 & 1.0 \\
Late & 38 & 3.5 & 13.0 \\
Could not be determined & $\mathbf{5}$ & $\mathbf{0 . 5}$ & na \\
Total deaths/verbal autopsy forms & $\mathbf{1 , 0 8 5}$ & $\mathbf{1 0 0 . 0}$ & na \\
\hline
\end{tabular}

na $=$ not applicable.

\subsection{Sociodemographic Characteristics}

The sociodemographic characteristics of the women between the ages of 12 and 49 years in the PDHS 2006-07 and included in this analysis are shown in Table 2. 
Table 2. Number and percent distribution of women 12-49 years of age, from 1,085 verbal autopsies, according to sociodemographic characteristics*

\begin{tabular}{lrr}
\hline Characteristic & Number & Percent \\
\hline Age (in years) & 206 & 19.0 \\
$<20$ & 309 & 28.5 \\
$20 \sim 29$ & 286 & 26.4 \\
$30 \sim 39$ & 273 & 25.2 \\
$40 \sim 49$ & 11 & 1.0 \\
Don't know & & \\
\hline Marital status & 741 & 68.3 \\
Married & 279 & 25.7 \\
Single & 11 & 1.0 \\
Divorced & 31 & 2.8 \\
Widowed & 10 & 0.9 \\
Separated & 13 & 1.2 \\
Don't know & & \\
\hline Education & 741 & 68.3 \\
No education & 161 & 14.8 \\
Primary & 67 & 6.2 \\
Middle & 68 & 6.3 \\
Secondary & 32 & 2.9 \\
Higher & 2 & 0.2 \\
Other & 14 & 1.3 \\
Don't know & & \\
\hline Employment status & 837 & 77.1 \\
Did not work for wages & 232 & 21.4 \\
Employed & 16 & 1.5 \\
Don't know & & \\
\hline *Percents do not always equal 100.0 due to rounding. & & \\
\hline
\end{tabular}

Of these women, 19 percent were teenagers at the time of their death. A majority had been married (68 percent) and 28 percent had been single. As for education, a majority (68 percent) of these women had not had any formal education, and only 15 percent had received primary education. The majority of these women had not worked for wages, though 21 percent were gainfully employed. Most of those who had worked had worked from home making handicrafts, like rilli (quilts), caps, etc. It could not be determined if the women who did not work had done so by choice or because there were no employment opportunities.

\subsection{Psycho-Socio-Cultural Factors Contributing to Deaths of Women of Reproductive Age}

The psycho-socio-cultural factors that contributed to the death of the women in this analysis were: poverty, neglect, ignorance, unsupportive family, domestic violence, disenfranchisement, superstition, spiritual/ritual treatment, low self-esteem, etc. Figure 1 shows the degree to which these factors contributed to the deaths of women in 
reproductive ages.

Figure 1. Percent distribution of cases according to psycho-socio-cultural issues that were found in a review of 1,085 verbal autopsies of women 12-49 years of age at the time of their death

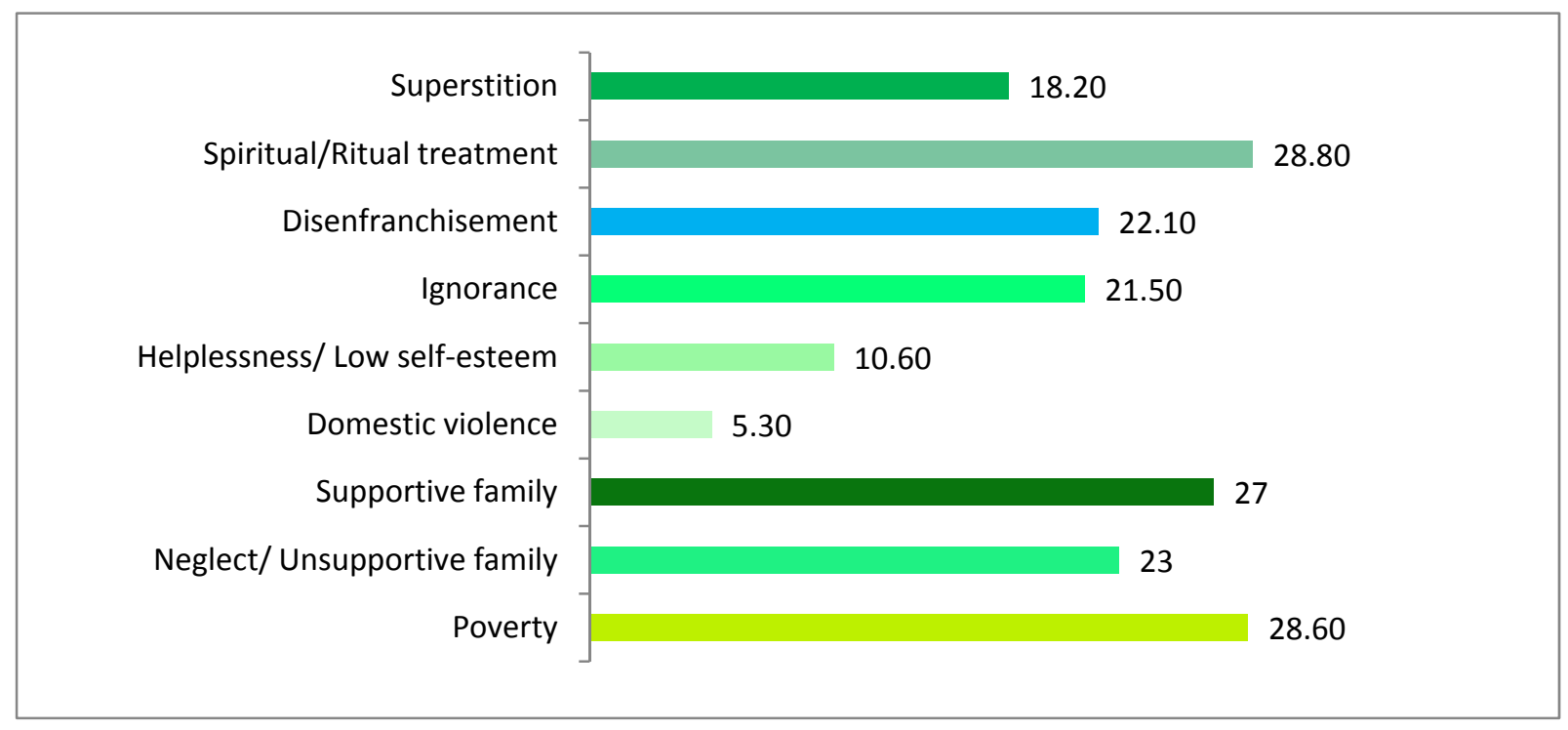

Poverty and spiritual/ritual treatment were identified more frequently than other issues (29 percent each). Disenfranchisement was a major cause contributing to the death of these women in almost one-quarter of the cases (22 percent).

\subsubsection{Poverty}

An overwhelming majority of the women had been poor. There were 310 documented cases (29 percent) of poverty, where the relatives narrated lack of money as a major reason for a delay in seeking treatment. The incidence of poverty dropped as education levels of the deceased women increased: 33 percent) for uneducated women versus 3 percent for women with higher education. Women's employment did not alleviate poverty: poverty was identified in 42 percent of the employed women and in 25 percent of the unemployed women.

Lack of finances led to a variety of consequences that included: spousal fights and sending the woman back to her parents house; not buying or taking prescribed medicines, or taking them irregularly; not seeking medical care; refusing hospital admissions and/or blood transfusions or surgery; not travelling to bigger cities to seek a higher level of care when referred by local doctors. 
As the medicines were very expensive -- so stopped taking them. "Chunkey dawayeian bohat mahngi theen is liye chor dein."

We took her to hospital, the doctor advised blood transfusion, but we had no money so came back. "Hum is ko hospital le gai they, doctor ne batayya isko khoon lage ga, bumaray paas paisay nabin they, hum log wapas aagaye."

She used to be worried/stressed due to poverty. The nurse advised to take her to [city] immediately but we brought her back home due to poverty. "Gurbat ki waja se thori peraishan rehti thee. Nurse ne kaha isi waqt [sheher] le jao mager gurbat ki waja se ghar le aye wapis." The decision to give birth at home, instead of in a health facility, was made due to poverty, as evidenced in this quote:

We could not get complete treatment as we are poor and therefore could only afford childbirth at home. "Mukammal ilaaj nahin hosaka kyun ke bum gharib log hein. Gurbat ki waja se delivery case ghar mein howa."

Poverty led to selling off of household valuables, including jewelry and animals and also collecting huge debts usually from the zamindar (landlord).

We spent a lot on the deceased, sold household things, jewelry and even borrowed money. "Murhooma pur baubat laga, ghar ki cheezein farokht ho gai, zevar bech diya, odhaar liya."

Due to inflation we had no money and were in debt of the landlord. Inflation and poverty with 9 children .... "Mehangai ki waja se hamaray paas paisay bhi nabin they, Pebley bi se zamindar ke qarazdar they, 9 bachoon ke sath mehangai aur ghurbat."

In some cases, due to extreme poverty, the family made a choice of utilizing the money to feed the family rather than seek medical care for the deceased.

We are very poor; we do not have money to feed ourselves, so how could we get her treated. "Hum khud bohat ghareeb hain, humarey paas khaney ke liye paise nabi hai, bum ilaaj kaise keratey."

There were also a couple of cases where the family sold off children, always girls, for paltry sums of money (e.g., Rs. 1000) to pay for the treatment.

Poverty also prevented some families from using preventive vaccinations (e.g., Hepatitis B). Though there was awareness about preventive vaccinations, they were perceived as expensive and beyond the means of the family. 
Sarkari (public hospitals) were generally viewed as places to seek treatment in desperate circumstances only; care there was cheap but people knew that quality care was not available there.

Spiritual or ritual treatment was resorted to due to poverty because these types of treatments are seen as cheap alternatives to care from trained health care providers.

\section{$\underline{\text { Hajran* }}$}

Hajran, a 40-year-old beggar, was married to another beggar. Hajran became pregnant 12 times; she delivered 8 children and had four miscarriages. Only four of her children were alive (3 girls and 1 boy).

She lived in abject poverty and used no contraceptives as she wanted more children. Hajran suffered from many chronic ailments, like hypertension, diabetes, epilepsy, asthma and tuberculosis. Though she took some treatment for tuberculosis off and on, she did not seek treatment for the other ailments.

Once, when she was five months pregnant, Hajran miscarried again while begging at a shrine. There was nobody to assist her. She continued to bleed heavily but did not seek any medical aid and only went home when she started feeling really unwell. She later became febrile, which lasted till she died about a month after the miscarriage.

Three days prior to her death she got into an argument with her husband who subjected her to severe physical abuse. Subsequently, she became very ill and the husband finally decided to take her to a hospital. He sold one of their daughters for Rs. 1000 to raise money for her treatment.

Even though transportation was readily available, she was made to walk for 5 hours to reach a government hospital. The doctors advised hospitalization, but the husband refused, saying that he did not have money. Hajran died at home later.

The most likely cause of Hajran's death was septic abortion.

*Note: All names bave been changed.

\subsubsection{Neglect (and/or Unsupportive Family), Ignorance and Beliefs}

Neglect/Unsupportive Family and Ignorance: Neglect, or an unsupportive family, was identified in 250 cases ( 23 percent). In more than 61 percent of cases there was not enough evidence in the verbatim reports to decide either way. Neglect was identified when poverty did not play a major role in the family decisions. In a majority of the cases, it became difficult to determine if the family decisions were due to neglect or ignorance.

In 233 cases (22 percent), ignorance was identified as a major factor leading to the deaths of women. 
After the birth of the second daughter while she was still in the puerperal period, she was exposed to wind/air and that resulted in joining together the veins of her brain. "Jab dosri bachi ki paidaish per mareeza cheeley mein theen tu hawa lagne ki waja se damag ki ragein jurh gai then."

I am scared of injection; I don't want to see any doctor, as everybody said there is no treatment for "black jaundice." "Mujhe teekon se dar lagta hai, mujhe kisi doctor key paas nabi jana 'Sub kebtey they kala yarqaan ka ilaaj nabi hai."”

In all cases where ignorance was identified as an issue, an additional contributory factor was neglect/unsupportive family. Lack of education was expressed by some respondents as a factor causing deaths where symptoms of disease were understood as effects of being possessed by jins (demons), etc. However, in a few cases (17 cases or 2 percent) there was deliberate neglect when ignorance did not play an important role.

The doctor had said the leg has to be amputated, the relatives got scared and brought her home and then never saw a doctor again. "Doctor ne kaha tha taang kaatni perey gi. Isi khauf se ghar wale inhein ghar ley aye aur phir ainda kisi doctor waqaira se ilaaj nahi kerwaya."

Belief System: Beliefs, traditional and/or cultural -- were sometimes important factors leading to the death of these women. (See also the section on superstition.)

If there is no problem during pregnancy, we, the women of [area] do not go to doctors for check up, nor do we think it's necessary to go to hospitals without a special reason. "Hum [area] ki khawateen baqair takleefya khas waja ke hamal mein kabhi bhi kisi doctor ko check nabi keratey na he haspataal jana zaroori samajbtey hain."

It is our family tradition that we marry off our sons and daughters while they are still very young. It is also our tradition and custom that we do not visit the doctor. "Humari khaandani rivayaat he ke hum log apne bete aur betion ki shadian chooti omar mein kar dete hein. Hamaari khaandani rasmo rivaaj ke mutaabik na koi doctor ke paas jaata he."

Cultural norms influence community and family attitudes not only in terms of health-seeking behavior, but also about the options that can be considered for curing specific problems. As the previous and following quotes suggest, marriage was, in some cases, believed to be a cure for all kinds of ills, from psychiatric disorders to menstrual irregularities. Cultural norms also influence the ways in which individuals are labeled as "good" or "bad;" it follows then that 
their illness/problem is the result of their own behavior or personality.

Everybody said get her married off and she will be fine. "Sabh ne ye kaha shaadi kardo theek ho jai gi."

She always suffered from great mental tension, and once when she was ill the doctor advised to marry her off as her "germs" were becoming poisonous. "Her waqt zebni tension mein rebti thee. Aik dafa bemaar bui tu doctor ne kaha iski fauri shaadi ker do kyun ke iskey jaraseem zebreley ho rahey hain."

The deceased did not have a good character. "[The deceased] ka kirdaar acha na tha."

\section{Zainab*}

Zainab was 24 years old and married to a laborer. Both of them were uneducated and lived in extreme poverty. The nearest freshwater supply was a stream accessible only on foot about 50 minutes away. Zainab worked as a farmhand to supplement the family income.

During her first pregnancy she developed generalized body swelling and gained a lot of weight. She also complained of severe headaches and blurring of vision. On account of poverty, the remoteness of their place of residence and lack of transportation, as well as in accordance with local customs, Zainab did not seek any antenatal care.

In the $9^{\text {th }}$ month of her pregnancy, the baby died while still in the womb. Despite the fact that two days had passed after the event and Zainab continued to suffer severe labor pains without the baby being delivered, her husband refused to take her to the hospital, insisting that she was not yet ready to deliver. Eventually, he agreed to make the trip to the hospital, taking her through the jungle along difficult mountainous terrain. Zainab died, undelivered, on the way to the hospital. Symptoms described are that of impending eclampsia, a lethal condition where she could throw up a fit anytime, but as she and her family were unaware of the danger signs or their significance, they did not seek medical help.

Ignorance and neglect were barriers to saving Zainab's life.

*Note: All names have been changed.

\subsubsection{Supportive Family}

In contrast to the psycho-socio-cultural factors included in this section that might have contributed to the death of the women in this study, the supportive role of the family was shown to be an important factor in trying to prevent a woman's death. Supportive families were identified in 295 cases (27 percent). This factor emerged clearly in the verbatim reports, where, in spite of poverty, disenfranchisement and other handicaps, the family went out of their way to help the woman and seek treatment for her illness. In the cases where Family 
support was identified, this support was seen to improve as the education of the deceased women increased: 46 percent of the women educated to middle-level schooling and 37 percent with higher education had supportive families, while 24 percent of the uneducated women had supportive families The presence or absence of a supportive family could not be identified either way in a majority of the cases (712 cases -- 66 percent). Finally, the degree to which the family's support might have made a difference in the absence of other factors that contributed to the death cannot be determined.

\subsubsection{Domestic Violence}

Different types of domestic violence were identified in 57 cases ( 5 percent) of all verbal autopsies. The violence was physical, emotional, verbal or economic. Physical violence accounted for 40 percent of the domestic violence cases. Physical violence ranged from physical beatings to forced housework and even hard labor on agriculture lands a couple of days before dying, in spite of serious illnesses. (Table 3)

Table 3. Deaths from domestic violence of 57 women $12-49$ years of age, from 1,085 verbal autopsies, according to type of violence

\begin{tabular}{lrrr}
\hline Variable & $\begin{array}{r}\text { Number of domestic } \\
\text { violence deaths }\end{array}$ & $\begin{array}{r}\text { Percent of domestic } \\
\text { violence deaths }\end{array}$ & $\begin{array}{r}\text { Domestic violence } \\
\text { deaths as a percent of } \\
\text { total deaths } \\
(\mathbf{N}=1085)\end{array}$ \\
\hline $\begin{array}{r}\text { Type of violence } \\
\text { Physical }\end{array}$ & 23 & & \\
Emotional & 17 & 40.4 & 2.1 \\
Verbal & 11 & 29.8 & 1.6 \\
Economic & 6 & 19.3 & 1.0 \\
Sexual & 0 & 10.5 & 0.6 \\
Stalking & 0 & 0.0 & 0.0 \\
Total & $\mathbf{5 7}$ & 0.0 & 0.0 \\
& & $\mathbf{1 0 0 . 0}$ & $\mathbf{5 . 3}$ \\
\hline
\end{tabular}

Domestic violence was highest in the separated women: 6 of the 10 separated women were subjected to violence ( 60 percent), followed by 3 out of the 11 divorced women.

Comparatively, only 31 of the 741 married women and 14 of the 279 single women (5 percent) experienced violent behavior from their family members (Table 4). 
Table 4. Deaths from domestic violence of 57 women 12-49 years of age, from 1,085 verbal autopsies, according to marital status

\begin{tabular}{lrrrr}
\hline & $\begin{array}{r}\text { Number of } \\
\text { domestic } \\
\text { Variable }\end{array}$ & $\begin{array}{r}\text { Percent of } \\
\text { domestic } \\
\text { violence deaths }\end{array}$ & $\begin{array}{r}\text { Total number of } \\
\text { violence deaths }\end{array}$ & $\begin{array}{r}\text { Domestic } \\
\text { violence deaths } \\
\text { as a percent of } \\
\text { total deaths }\end{array}$ \\
\hline Marital status & & & & \\
Married & 31 & 54.4 & 741 & 4.2 \\
Single & 14 & 24.6 & 279 & 5.0 \\
Separated & 6 & 10.5 & 10 & 60.0 \\
Divorced & 3 & 5.3 & 11 & 27.3 \\
Widowed & 2 & 3.5 & 31 & 6.5 \\
Don't know & 1 & 1.8 & 13 & 7.7 \\
Total & $\mathbf{5 7}$ & $\mathbf{1 0 0 . 0}$ & 1,085 & $\mathbf{5 . 3}$ \\
\hline
\end{tabular}

*Note: Percents do not total 100.0 due to rounding.

The perpetrators were mainly husbands, but all categories of relatives were involved. Those involved included the woman's own family and her in-laws, from fathers, brothers, nephews, uncles, and parents-in-law, especially the mother-in-law, etc. The husbands would beat them sometimes on their own and at other times after being encouraged by his family members.

Due to his family's influence the husband would beat her real hard.

"Murhooma ka miya ghar valloon kay bhakavey may aakur murhooma ko bohat maarta tha."

A few women were physically abused and beaten during pregnancy and then sent away to their parents close to the time of expected childbirth, thereby saving the husband from the expenses that could have been incurred during childbirth. Women returned to their parents' houses (the house of a woman's parents is referred to as maika) for a variety of reasons other than physical violence or economic factors, such as after the birth of a girl child.

The deceased would often return to her parents' home to stay, especially during pregnancy the husband would send her to her parents' home, so that she would deliver there and he will be saved from the expenditure of childbirth. Last time he beat her severely, tore off her earrings from her earlobes and turned her out of the house. For the past 6-7 years she lived with her parents along with her children. "Marhooma akser aukaat apney maikey mein aaker rebti thee. Khas taur per jab hamal mein zajgi ka waqt kareeb hota tha tu kharchey key khoof se marhooma ko maikey bhej deita. Akhri mertaba miyan ney bohat maara peeta tha, baaliyan nouch ker ghar se nikal diya tha. wo bachon samet maikey mein rehney lagi. Marohma taqreban 6-7 saal se maika mein rehti thee." 
She experienced a lot of violence in her in-laws' house. Husband beat her severely and gave her no money. For these reasons we brought our daughter back home and 3 months later he sent the divorce papers. "Susral mein bohat tashadood hota tha. Khawand bohat maarta tha, Kharcha bhi nabi deita tha. Inbi wajohat ki bina per bachi ko ghar bitha liya aur 3 maah baad damad ney talaaq bhijwa di. "

After the birth of a girl the in-laws' behavior became really bad. The motherin-law and her husband were very angry and she came back to live with her parents. "Bachi ki paidaish ke baad susraal walon ka rawayya intibai bura ho gaya. Bachi ki paidaish par shanahar aur saas ne khaasi naraazgi ka izhaar kiya aur wo maan baap ke ghar aagai."

Emotional violence was due to a variety of reasons, reflected in the quotes above, and could occur when the husband was not working and even when he was working and would not give money to his wife. He might be indulging in drugs and being violent under its influence.

My father was an addict and under the influence of drugs would often beat my mother black and blue. "Abu nasha kertey they aur akser ammi ko peeth bhi liya kertey they."

Severe emotional violence was described where girls were forced to marry against their will and, if they resisted, were usually killed by their own family members. A husband's desire for remarriage also leads to great emotional stress for some women. Husbands with more than one wife also were said to cause severe emotional and mental stress when they favored one wife over the other. Severe emotional stress also affected a few women who were constantly being threatened with of divorce by their husbands.

The husband would tell her that he did not like her and would divorce her. He used to beat her too! "Shauhar kehta tha ke tum mujhe pasand nabin ho. Mein tumbey talaaq de doon ga, shaubar isko maar peeth bhi karta tha."

In the verbatim reports, there were also reports that some women, probably due to stresses in their lives or some psychiatric illnesses, would beat their family members, including husbands and children. 


\section{$\underline{\text { Surraya* }}$}

Surraya, a 38-year-old mother of 4 ( 2 girls and 1 boy living), was subjected to severe beatings by her husband and in-laws on a regular basis. She would escape to her parent's home, only to return and face more violence. She suffered even more severe violence during the later stages of her pregnancies and was then thrown out of the house, possibly to avoid bearing the childbirth expenses.

About 6-7 years before her death she was beaten black and blue by her husband, who also ripped the earrings off her ears and turned her out of the house yet again. For the rest of her life she lived with her parents along with her children. She had chronic cough and chest pain since childhood, but the only treatment ever sought was from faith healers. She never received any proper medical treatment and died in her parents' home. When seen by doctors in her terminal illness it was suspected that she was born with some heart defects.

After her death the children continue to live with their maternal grandparents; their father visits them sometimes.

*Note: All names have been changed.

\subsubsection{Disenfranchisement}

In this instance, disenfranchisement refers to lack of availability or accessibility of health services. In quite a few cases it was difficult to separate poverty and disenfranchisement as the main factor contributing to death as they appeared to interact in these deaths.

In 240 cases (22 percent), accessibility of health services was a big hindrance to obtaining medical care. Services were inaccessible mainly due to crumbling infrastructure, difficult terrain, and kutcha (mud/remote) areas, which were often flooded, especially in the rainy season, etc. This was a problem in rural areas and in much of Balochistan.

This is a mountainous area, there are no roads. We carried the deceased down the mountain on a charpoy (bed) till we reached a road and then took her in a car. All this took a long time. "Yeh pahaari ilaaqa hai, road nabin he, murbooma ko pabaar se utartey waqt chaar pai par le jaya gaya aur road par paubanch kar unhein gaari mein le jayya gaya. Us mein kaafi time lagga."

It was rainy season when her labor pains started. The dai (traditional midwife) could not be found, so her mother and mother-in-law, together, conducted the delivery. It was night time where could we go? The taxi had already left and with great difficulty we put her in a rickshaw. "Murhooma ko dard shoroo bua to barsaat thee. Dai nabin mil sakti thee, is liye maan aur saas ne mil kar delivery kurwai. Raat ka waqt tha, kahan jaatey, taxi bhi chali gai thee, barri mushkil se us ko rickshaw mein dala." 
Transportation creates major problems for accessing care, especially in an emergency. Nonavailability of transport, whether due to difficult terrain, bad roads, or the absence of public transport or ambulances is a big issue in rural areas, again, especially in Balochistan. Getting transport, especially at night, was often difficult or impossible. Families would wait overnight, even in extreme cases, hoping to find transport when morning came.

There is no transport available at night and if the hospital was near our village we could have taken her for treatment. We therefore decided to give her medicine at home during the night and take her to hospital when the morning breaks, but perhaps this was the extent of her life. "Haspataal ager nazdeek gaoon mein hota tu hum ley jaatey kyun ke garriyan bhi raat ko nai milti. Hum ney kaha raat ko yaheen dawaee deitey hain aur subha ley jayen gay magar inki zindigi shaid itni be thee."

There is just no transport available at night. She could not even sit on the donkey cart. Doctor was far away. Had we gone to THQ hospital we knew there would be no doctor there, it would have been a waste of time, so we just waited for the morning to break. "Raat ko sawaari milti hi nabin. Wo ghaday gaari par bhi nabin baith sakti thi. Doctor yahan se baubat door hai. Agar bum THQ jatey to wahan par koi doctor nahin

The respondents also generally complained of nonavailability of health facilities in their areas. If there were physical structures present, they reported that the equipment, medicines and/or staff were not there, so that if a woman in critical condition did reach a hospital, it was unlikely she would receive proper treatment as the hospitals were closed or doctors absent on weekends or public holidays (e.g., Eid and Muharram), or during/after natural calamities that tax the capacity of the facility (e.g., after an earthquake, like the one in Pakistan in 2005).

There are no hospitals in our area, if there is a hospital it is in ruins, doctors and equipment are just nowhere to be seen. "Na bumarey ilaaqey mein koi haspatal hai, agar haspatal hai to bilkul khandraat hai, saaman aur doctor ka naam o nishaan hi nabin hai."

The hospital was chock-a-block with patients due to the earthquake. "Zalzaley ki waja se haspatalon mein rush bohat zada tha."

In our city, no matter what happens the doctors don't see the patients at night. "Humare shaher mein kuch bhi ho jaye doctor raat ke waqt mareez ko daikhney 
nabi aatey."

Some respondents also complained of the absence of female medical staff.

Health facilities are just not there. There is no lady doctor in our area and neither do we have money to seek treatment. "Hur waqt ilaaj ki sahulat mein kami thee. Humarey ilaaqey mein koi lady doctor nabin hai $\mathrm{Na}$ bi paisey hein le janey ke liye."

The attitude of the health care providers, including doctors and nurses, was perceived as inhumane and devoid of any empathy, The competence of doctors was questioned, especially those at public hospitals, which are perceived as places where quality treatment is not available. Some respondents reported that the doctors lacked the necessary knowledge and skills.

Doctors' attitude in the hospital is not good. They misbehave with patients and their attendants. The doctors in the government hospital said she had a tumor but as the hospital was not equipped they advised us to take her to [a major city]. "Hospital ke doctor ka rawayya acha nabin. Wo marizon aur sath walon ki be izatti karte hein. Koi ikhlaaq nahin. [Government health facility] wallon ne rasuli batai lekin operation ka samaan nabin is liye [a major city] janey ko kaha."

The doctors here are such that they cannot even treat simple fever. "Humarey yahan doctor bhi aise hain ke bukhar ka ilaaj nabi ker saktey."

We took her to Dr. [name deleted], we and the qari (religious man) begged and cajoled her to do something to stop the bleeding, but she paid no attention and said she cannot deal with this case as it is beyond her capability. "Dr. [name deleted] ke paas le kar gaye, hum ne khud aur qaari ne mannat sumajat ki ke kuch karo ke khoon ruk.jai. Lekin us ne koi tawajja nabin dee. Kaha ye case mujh se sumbhla nabin jaye ga."

\subsubsection{Superstition}

It is commonly believed that when a woman falls ill, especially if young, she is, in fact, possessed or under the effect of one of the following: a jin (demon); a saya (shadow), or asar (effect). It may also be that her ill health is said to be caused by somebody casting an evil eye or a magic spell, or, even worse, if her condition is due to black magic. Superstition was a big reason for delays in seeking appropriate treatment and resulted in the death of 198 women 
(18 percent). Education had no effect on superstitious beliefs and mortality: 18 percent of uneducated women and 19 percent of highly educated women eventually died in cases where superstition contributed significantly to their deaths. Terminologies, like sifli, etc., were used by respondents; some of these terms were not commonly understood by reviewers.

The family thought that she was possessed by a demon. "Ghar waloon ka kehna tha key marhooma ko jin they."

Maybe somebody had hit the deceased or somebody had made amulets against her or something had suddenly possessed her. "Marbooma ko kisi ney maara hai. Shaid kisi ne taweez kiye hon ya kisi cheez ka achanak saya ho gaya ho."

[Name deleted] was possessed by a shadow, somebody had done black magic on her, and the more we treated her, the worse she became. "[Name deleted] ko sayya tha, kissi ne kaala jadu kia tha, kyun ke agar hum ilaaj kurwatey to ziyada haalat kharaab hoti."

The moulvi said she had the effects of bad/evil eye. "Maulvi ne kaha tha ke bud nazar laga be."

She had the effects of the shadow and had no major disease. Everybody focused on the 'shadow' and took treatment and amulets from the bhawaya (Hindu faith healer). "Unko oopar ka saya asar ho gaya tha. Warna koi barri bimaari na thi.sabh ne oopar ke asar honey par tawajja di aur bhaway se taweez aur ilaaj karai."

Symptoms of serious illnesses are perceived as due to being loved by a demon.

Before marriage she was loved by a demon. Whenever she would wash her face it would swell up. The demon would not allow her to wash her face, but in spite of not washing her face her condition was not improving. "Shadi se peble bhi is khatoon per jin aashiq tha. Sabun se moun dhoney se moun sojh jata tha. Isko jin nabi dhone deita tha. Phir bhi behtri nabi aa rabi thee kyun ke jin aashiq tha."

When the illness is thought to be due to "being loved" by a demon or a similar cause, then treatment is sought from a faith healer. This is especially true if the woman was described as young and beautiful by the relatives.

Urinating in graveyards, under the trees or in open spaces was commonly believed to be a reason for being possessed by a jin. 
In my opinion, my daughter was possessed by a shadow. Once she urinated on a tap where amulets were tied to it and then became ill. "Meray kbyaal may meri bachi ko saya ho gia tha. Aik dufaa bamarey nalkay pur taveez bunday hoa they, or marhooma nay vahan naklay may baith kur pishaab kiya tha. Is key baad marhooma ki tabiyat kharaab hoi hay."

The deceased had urinated under a tree in the park and perhaps this was the reason for her being possessed by a shadow. "Marhooma ne park mein aik darakht ke nichey pishaab kiya tha iski waja se is per saya hai."

She used to urinate on the holy man's grave and, therefore, his shadow was affecting her. "Faqir ki qabr par peshaab karti thi is liye is par faqir ka saya bo gaya."

All kinds of ailments are attributed to tubal ligation, ranging from obesity to cancers. It was also believed to bring bad luck and considered a bad omen for the family.

The deceased had an operation to stop having more children 4 years ago and then developed cancer of the womb. "Marhooma ney 4 saal pebley bacha band kerne ka operation kiya tha aur 4 saal baad bacha daani mein cancer ban gaya."

Family planning use is also believed to bring bad luck like the death of a child.

A 2-year-old son of the deceased fell off the roof and died. She was depressed because of it and would often talk about him. She then stopped using the family planning method and became pregnant by choice. "Murhooma ka aik bacchaa jis ki omar taqreeban 2 saal thee, chat se girnain ki waja se wafaat pa gaya, murhooma ko is ka bauhat ghum tha isse bauhat yaad karti thee. Is ke baad unhon ne family planning jo wo kar rabi theen us ko chora aur apni marzi se hamla hoi." 


\section{Nasira*}

Thirteen-year-old Nasira was single and lived in a joint family system headed by her paternal grandfather, who apparently had total control over family matters. She was a student of class 5 and had not yet seen periods. According to the grandfather, she was a much- loved and well cared for child who looked older than her years.

Nasira enjoyed good health but one day, two months before her death, she complained of severe headache and vomiting for which her grandfather consulted a local doctor who prescribed some medicines. However, this provided no relief and she was then taken to a hospital, where she was investigated and a CT scan also performed. The doctors informed the family that the scan and other tests revealed no abnormality.

She was then taken to a shrine to see a pir (saint). He performed dum (to repeat incantations and blow upon the person) and gave her a taweez [amulet] to wear and told the family that she had been possessed by a jin (spirit/saya) called Gulshan. The spirit had vowed revenge as Nasira had desecrated the spirit's house by urinating there, which was located in a mazaar (graveyard) near Nasira's school.

Nasira was then taken to several pirs, including ziarats (shrines) in other locations. All of them confirmed that she was indeed possessed. One pir told them that the spirit would visit Nasira every Tuesday. Following this, Nasira started suffering from severe headaches and vomiting on Tuesdays. She used to say that she could see a woman in a black dress.

The family engaged a pir to come to their house every Tuesday in order to exorcise the spirit (perform a dum). The spirit one day announced that it was going to go away but would come back after a month to take Nasira away with her. After that the family started hearing strange noises in the house.

Nasira was later taken to another pir, following which she remained well for one month. Then one day, she complained of severe headache and vomiting. She asked for the grandfather to come to her assistance. He fed her breakfast and Nasira rested with her head on his shoulder, 15 minutes later she died.

Strangely, neither of Nasira's parents nor any other family members are involved in her care; some respondents are reported as her in-laws though she was single.

Nasira's cause of death remains a mystery.

*Note: All names bave been changed.

\subsubsection{Spiritual/Ritual Treatment}

Looking for a cure using spiritual or ritual treatment was sought in 312 cases (29 percent). Unfortunately, valuable time was lost while trying to find a spiritual/ritual cure for the deadly conditions these women were suffering from.

Spiritual/ ritual treatment was sought by women with all levels of education; there was no difference between educated and uneducated women as far as seeking spiritual/ ritual treatment is concerned (uneducated - 30 percent; secondary education - 29 percent; higher education - 22 percent). 
These faith healers have been variously described as pirs, faqirs, baba, sain baba, amil, amil baba, faqir baba, bhawaya, murshid, kohli faqir or even the village moulvi. A majority of these faith healers were men though a few were females.

Spiritual and/or ritual cures were especially sought in chronic illnesses. These treatments consisted of taweez (amulets), dum and darood (e.g., water and thread on which verses of the Quran were recited and then air in the mouth blown over it -- "dum kiya bua /parba bua pani and dhaga"); the threads were worn by women around their necks and the water was either drunk or sprinkled on the person). Sometimes the taweez is also soaked in water and the water drunk. In some cases, massage with parha bua" oil was also used as a remedy.

She would wear the "read thread*" and rub the "read" oil on her body. Sadka [sacrifice of some animal or money given to poor] was also done. [*Verses are recited by faith healers and air in their mouths is blown over the thread, oil or water.] "Dhaga perbwa kar pehnaya tha. Tail perha hoa jism per lagati thee. Sadka bhi diya tha."

Sometimes the treatment included violent beatings leading to serious bodily harm. These women would sometimes go from shrine to shrine and spend weeks and months looking for a cure for their ailment. At times, the women were left at the shrines with the pirs.

Fifteen to twenty days before her death, she went to the moulvi for dum and stayed there for 10 days. Then she came home and 2-3 days later went again for 10 dums. The deceased died in the moulvi's home. Dum was done for her; she drank water of dum and also wore taweez [amulet]. "Marhooma ki wafaat se taqreeban 15-20 din pebley maulvi se dum rekhwaney gayi aur dus din waheen raheen. Phir ghar ley aye. Do teen din key baad mazeed dus dum kerwaney gaye. Marbooma ki moaut maulvi key ghar per hui. Dum bhi kerwaya, paani bhi dum ker key pilwaya. Taweez bhi diya."

She used to live on the shrine, wear an amulet around her neck and drank the holy water. "Durgah par rebti thee, taweez, galle mein dalle hoi the, purba howa paani peeti thee."

Other rituals described for treatment include lighting candles and the woman watching them for 41 days, or sprinkling sugar and chilies on ancestors' graves and inhaling smoke, especially after burning red dried chilies, described as dhoni.

We asked a lady to do dum. She said the cancer had spread and advised to sleep at night with a candle, a knife and oil on her bedside and the demon 
will then perform the operation. "Kissi aurat se dum kurwaya. isne kaha cancer phail gaya hai, aur kaha ke raat ko apnay paas choori, tail aur moom batti rakh kar sona, jinn tumbara operation karein ge.”

Amulets were tied around her arm, water was sprinkled, oil lamps were lit and [name deleted] Bibi was asked to watch it for 41 days. "Taweez bazoo pur bandhi, paani bhi chirka, chiraagh jalaaya aur [name deleted] bibi ko 41 days tak dekhne ko kaha."

The amulet man said she has the shadow of her mother over her and then we spilt sugar and chilies on our maternal grandmother's grave and she became alright. "Taweez. walley ne kaha is ki maan ka saya is ke oopar aaya hai, phir cheeni aur doodh meri naani ki qabr par daal kar aai phir wo theek ho gae."

These faith healers play with the lives of people and give statements like:

We saw the moulvi and he said she had äsar [was possessed], gave her water after dum and said there was nothing wrong with her. "Maulvi sabib ko dikhaya, inho nay bataya kay asar hai, or pani dum kar kay diya, or kaba is ko or kuch bhi nabi bay."

If the family was a Syed they did not depend on others, preferring to do the rituals themselves.

Gave her the holy water to drink as we are the Syeds, we make the water holy ourselves [by reciting the verses of Quran and blowing over the water]. "Paani dum kiya hua pilaya tha, kyun ke sayed khandan hai, paani khud he dum ker ke pilatey they." 


\section{Nooran Bibi*}

Nooran Bibi was 32 years old, illiterate and married to a laborer. She had no health issues before marriage but stopped menstruating 4-5 years after marriage. Over the years, she consulted several doctors for her inability to have children.

She was under great stress over the fact that she had no children. Her behavior had become so erratic that people thought she had gone mad. She would shower several times a day and scratch herself till she drew blood. She also suffered from fits at times. About a month before her death her symptoms became worse and she was taken to a bakeem (trained in Unani/ Greek medicine), who performed dum (to repeat incantations and blow upon the person) on her and gave her a taweez (amulet) to wear. The hakeem went on to play some music and gave her something to eat. He then subjected her to a severe beating following which she became so unwell that she had to be carried back home on a charpoy (bed).

The family then consulted another hakeem in their village who also performed a dum and gave her another taweez: On the day of her death, Kubra suffered a fit after which the local doctor was called in. The doctor informed the family that she was unlikely to survive. The family said that they spent Rs. 5000 of borrowed money on her treatment but owing to extreme poverty were unable to consult a "big" doctor.

*Note: All names have been changed.

\subsubsection{Low Self-esteem/Helplessness/Depression}

This issue was identified in 115 of the cases (11 percent) where it was felt that due to the circumstances the woman felt helpless and depressed and this prevented her from seeking treatment/help. This helplessness was described as like being eaten up by a termite and just existing as a shell with nothing inside.

The deceased was burdened with grief and this really ate her up from inside. "Murbooma zabnee tor pur bohat dukhoon aur sadmoon sey dochar thee aur ye cheezen usko ander se khokbla kerti gayein."

Low self-esteem due to not producing a son and being a mother of several daughters was a big issue in the lives of some women and their respite lay in sleeping.

She would always be sleeping due to worries about household matters. The husband was not working and no son - only daughters. There was just no mental peace. "Gheraloo peraishaaniyon ki waja se soti rehtee theen. Shoher kaam nabi kerta tha. Beta koi nahi, baiteeyan he hain. Zehni sakoon khatam ho gaya tha."

Poverty, discussed earlier, was responsible for desperate situations in which women seemed resigned to their fate, though certainly, as this quote reflects, this must have caused a sense of futility and depression. 
We are poor people, where can we get money? There is not enough money to buy flour, the doctor charges Rs. 40 so how can we pay for the medicines, We just die and our family then bury us and the husband gets a second wife. "Hum ghareeb loag hain, paise kahan se lain. Aata bhi pura nabi hota hai doctor tu 40 rupai fees lete hain phir dawain kahan se lain, bus mar jate hain aur ghar wale dafna kar aate hain. Shohar doosri shadi kar lete hain."

\section{Rukhsana*}

Rukhsana was a 22 -year-old healthy, uneducated young woman who had been married for only two months. She lived in a kutcha (mud) house with her husband who was 20 years old and worked as a farm hand.

Her marriage had been arranged against her wishes, in accordance with the custom of watta satta whereby her brother had married her husband's sister. She only consented to marry once she was given to understand that if she did not like her husband she would be allowed to dissolve the marriage. She found no affection for her husband and wanted to end the marriage. In the two months following the marriage she went to her parents' house several times, asking that the marriage be dissolved, but her family refused to oblige, sending her back each time. The last such event occurred just 4 days prior to her death.

On the day of her death, her brother came over to her house and she demanded that he take her back with him. He, however, refused and left for home. Rukhsana tried to follow him but her brother sent her back. Later, she asked her husband to escort her to her parents' house but he refused, too, saying that he would take her later since he was tired after the day's work.

Later in the day she vomited some yellow substance and, upon being asked, informed her husband that she had consumed some poison. Soon afterwards she vomited blood. Her husband took her to the local hospital which was about 25 minutes away. She was given some treatment and was reassured that that she would recover. She died two hours later.

Her in-laws were depressed over the fact that as a consequence of Rukhsana's suicide, their daughter who was married to Rukhsana's brother was now not allowed by her in-laws to visit her family anymore, as they had incurred a heavy debt for Rukhsana's marriage and felt that it had turned out to be a complete waste.

*Note: All names bave been changed.

\subsection{Ambivalent Deaths}

In none of the 1,085 cases was there a conflict in determining the category of death. However, in 10 cases there was ambivalence in the cause of death (Table 5). In these 10 cases, the circumstances leading to death, as narrated by the respondents in the verbatim reports, were in conflict with what had been said by neighbors or other family members (e.g., according to the information given by the respondents the woman had met an accidental death or died of a disease, but the information provided by other people pointed toward homicide or suicide). In these deaths, a review of the verbatim reports indicated a 
number of psycho-socio-cultural factors underlying the death, such as: husband's desire to remarry, extramarital affair leading to honor killing, the woman being married against her will, fight with brothers, broken engagement, and difficulty in getting married to the man of the woman's choice. In these cases, it seems apparent that these factors led to the death of these women, either by their own hand or by those supposedly close to them. In none of the 10 cases was there evidence that the death resulted from complications from abortion or miscarriage.

Table 5. Variables for 10 cases where the underlying cause of death was ambivalent for women 12-49 years of age, out of 1,085 verbal autopsies reviewed

\begin{tabular}{|c|c|c|c|c|c|c|c|}
\hline No. & Age & Marital status & Education & Respondent & $\begin{array}{r}\text { Cause of death } \\
\text { narrated by } \\
\text { respondent }\end{array}$ & $\begin{array}{r}\text { Cause of } \\
\text { death narrated } \\
\text { by others }\end{array}$ & $\begin{array}{r}\text { Underlying cause of death and } \\
\text { comments }\end{array}$ \\
\hline 1. & 42 & Married & Primary & Mother-in- law & Heart attack & $\begin{array}{r}\text { Honor killing } \\
\text { by a nephew } \\
\text { (brother's son) }\end{array}$ & Mother of 7 . Extramarital affair \\
\hline 2. & 19 & Married & Middle & Other relative & $\begin{array}{r}\text { Suicide by } \\
\text { hanging }\end{array}$ & Homicide & $\begin{array}{r}\text { Husband wanted to remarry: } \\
\text { married on the } 3^{\text {rd }} \text { day after her } \\
\text { death }\end{array}$ \\
\hline 3. & 23 & Married & None & Mother-in-law & Heart attack & Electrocution & Husband wanted to remarry \\
\hline 4. & 15 & Never married & Primary & Mother & Diarrhea & $\begin{array}{r}\text { Suicide by } \\
\text { ingestion of } \\
\text { tablets }\end{array}$ & $\begin{array}{r}\text { Broken engagement and ex-fiancés } \\
\text { marriage }\end{array}$ \\
\hline 5. & 20 & Never married & Primary & Mother & $\begin{array}{r}\text { Accident }- \\
\text { burned }\end{array}$ & $\begin{array}{l}\text { Suicide or } \\
\text { Homicide }\end{array}$ & Fight with brothers \\
\hline 6. & 20 & Married & None & Mother-in-law & Suicide & Homicide & $\begin{array}{r}\text { Married against her will. In love } \\
\text { with somebody else }\end{array}$ \\
\hline 7. & 15 & Never married & Primary & Mother & $\begin{array}{r}\text { (Meningitis) } \\
\text { Evil Eye/ } \\
\text { Nazar lag gai thi }\end{array}$ & $\begin{array}{r}\text { Suicide by } \\
\text { ingesting } \\
\text { sleeping pills }\end{array}$ & Could not be determined \\
\hline 8. & 22 & Never married & None & Sister & Suicide & Homicide & Fight with brother \\
\hline 9. & 22 & Never married & Higher & Aunt & $\begin{array}{r}\text { Accident - } \\
\text { electrocution }\end{array}$ & Homicide & Could not be determined \\
\hline 10. & 16 & Never married & Middle & $\begin{array}{r}\text { Father and } \\
\text { brother (who } \\
\text { murdered her) }\end{array}$ & $\begin{array}{r}\text { Heart } \\
\text { attack/Thyroid } \\
\text { disease }\end{array}$ & $\begin{array}{r}\text { Strangled with a } \\
\text { dupatta by her } \\
\text { brother }\end{array}$ & $\begin{array}{r}\text { Wanted to marry a boy. In a } \\
\text { relationship }\end{array}$ \\
\hline
\end{tabular}

There were another 50 women, out of the 1,085 verbal autopsies reviewed, who died suddenly or following a brief illness. In these cases, no conflicting reports were available. Nevertheless, there was a common pattern seen in their deaths. The women were all young (a majority below 20 years of age) and were described as beautiful and previously in good health. The other thing these women had in common was that their deaths were ascribed to heart attack or baiza (cholera/ severe vomiting and diarrhea), and these deaths were readily accepted as the will of Allah: 
Her moment had come. "Us ka waqt aa gaya tha."

But perhaps this was the span of her life. "Magar inki zindigi shaid itni he thee."

When she did not take her medicines how could she get better? Everybody has to die and she died as well. "Tab dawa nabi khati thi tu kaise faraq bu sakta tha. Sub ko marna hai who bhi mar gai."

This last statement was made by the brother who, according to a neighbor, had actually strangled his sister with her dupatta (scarf) for her crime of wishing to marry the young man of her choice. In this case, the family said she had died of a heart attack.

The verbatim reports in these 50 cases were usually very brief. It was very difficult to assign any definite cause of death in these cases. Assumptions can be made, including anything from homicide/suicide to abortion-related cause of death.

Table 6. Number and percent distribution of 60 ambivalent deaths, from 1,085 verbal autopsies, according to characteristics of the deceased women

\begin{tabular}{lrrrr}
\hline Characteristic & $\begin{array}{r}\text { Total number } \\
\text { of deaths }\end{array}$ & $\begin{array}{r}\text { Number of } \\
\text { ambivalent deaths } \\
\text { (confirmed and } \\
\text { suspected) }\end{array}$ & $\begin{array}{r}\text { Ambivalent } \\
\text { deaths as a } \\
\text { percent of total } \\
\text { deaths }\end{array}$ & $\begin{array}{r}\text { Percent of } \\
\text { ambivalent } \\
\text { deaths by } \\
\text { characteristic }\end{array}$ \\
\hline Age & & & & \\
$<20$ & 206 & 34 & 16.5 & 56.7 \\
$20-29$ & 309 & 20 & 6.5 & 33.3 \\
$30-39$ & 286 & 2 & 0.7 & 3.3 \\
$40-49$ & 273 & 3 & 1.1 & 5.0 \\
Don't know & 11 & 1 & 9.1 & 1.7 \\
Marital status & & & & \\
Married & 741 & 21 & 2.8 & 35.0 \\
Single & 279 & 38 & 13.6 & 63.3 \\
$\quad$ Divorced & 11 & 1 & 9.1 & 1.7 \\
Separated/Widowed/ & & & & \\
$\quad$ Unknown & 54 & 0 & 0.0 & 0.0 \\
Education & & & & 48.3 \\
No education & 741 & 29 & 3.9 & 16.7 \\
Primary & 161 & 10 & 6.2 & 13.3 \\
Middle & 67 & 8 & 11.9 & 18.3 \\
Secondary & 68 & 11 & 16.2 & 3.3 \\
Higher & 32 & 2 & 6.3 & 0.0 \\
$\quad$ Other/Don't know & 16 & 0 & 0.0 & $\mathbf{1 0 0 . 0}$ \\
Total & $\mathbf{1 0 8 5}$ & $\mathbf{6 0}$ & $\mathbf{5 . 5}$ & \\
\hline
\end{tabular}

An analysis of the characteristics of these women reveals some insights. With advancing age, the incidence of ambivalent deaths (confirmed and suspected) was lower (Table 6). Findings show that the incidence of confirmed and suspected ambivalent deaths was highest in women with secondary education, decreasing with declining levels of education. Though the 
incidence for women with higher education was lower and for uneducated women lower still. In addition, the incidence of ambivalent deaths (confirmed and suspected) was highest in single women. The incidence for married women was much lower. For divorced women the number is so low that the incidence in this group cannot be determined. No ambivalent death was identified in separated and widowed women.

\section{$\underline{\text { Rabia* }}$}

42 year-old Rabia was very beautiful and had recently moved to Rawalpindi along with her husband, who worked as a mason. She also stitched clothes to help supplement the family's income. She was the only sister of seven brothers.

She gave birth to 10 children, of whom 7 (all boys) were alive. At the time of her death, her youngest son was 3 years old. A month after moving to the city, she befriended a married Pathan man and eloped with him. Her brothers managed to recover her with the help of police. As a result she spent a few days in the police lock up. Once released, she went to live with her parents, as her husband was not willing to keep her in his house anymore. He did however agree to bear the expenses of his kids.

According to her mother-in-law, Rabia died of a heart attack, but according to Rabia's son, who the interviewer bumped into accidentally in the street, said she was killed by her nephew. One of Rabia's brothers (who lived abroad) on hearing about his sister's escapade was really enraged and called one of his nephews and directed him to kill Rabia. He promised to bear all the legal expenses that would be incurred as a result of the honor killing.

*Note: All names bave been changed.

\subsection{Maternal Deaths}

\subsubsection{Late Maternal Deatbs}

Of the 1,085 verbal autopsies reviewed, 38 cases of late maternal death were identified. There were 10 deaths due to direct causes and 28 due to indirect causes (Table 7). Some late maternal deaths that were due to coincidental causes were also identified; however, these were not counted in the late maternal deaths. 
Table 7. Distribution of 38 late maternal deaths of women 12-49, from 1,085 verbal autopsies, according to cause of death

\begin{tabular}{lr}
\hline Cause of death & Number \\
\hline Direct causes & 3 (1 unsafe) \\
Abortion related & 4 \\
Septicemia following puerperal infection & 3 \\
Complications of surgery & $\mathbf{1 0}$ \\
Total & \\
Indirect causes & 6 \\
Cardiac disease & 7 \\
Tuberculosis & 4 \\
Liver disease & 5 \\
Cancer & 3 \\
Severe anemia & 2 \\
Cerebra vascular accident (stroke) & 1 \\
Septicemia following urinary tract infection & 28 \\
Total & 2 \\
\hline
\end{tabular}

Of the 38 late maternal deaths, 3 were abortion related, mainly due to sepsis. In 1 case, the woman had undergone an unsafe abortion, while in 2 cases it was not clear if the abortion was induced or spontaneous. Iatrogenic causes, defined as treatment failure or complications of medical procedures were identified in 3 cases (death shown as due to surgery). Liver diseases were identified as the cause of death in 4 cases.

\subsubsection{Reassessing Category of Maternal Death}

In the process of reviewing maternal deaths, there were 3 maternal deaths that were recategorized as "maternal deaths but cause undetermined." Of these, 2 were previously categorized as direct maternal deaths and 1 as coincidental maternal death.

\subsubsection{Unpacking Indirect Maternal Deaths}

Maternal deaths due to indirect causes are all grouped together as per ICD 10 coding. In an effort to better understand the causes of maternal deaths, 49 maternal deaths due to indirect causes were unpacked (Table 8). When unpacked, the most common cause of death in these cases was shown to be liver diseases, which were responsible for 26.5 percent of indirect maternal deaths, followed by cardiac diseases (20 percent). Of the iatrogenic causes, 3 deaths were due to mismatched blood transfusions and 1 was due to drug reaction. 
Table 8. Unpacking indirect maternal deaths: Cause of 49 indirect maternal deaths of women 12-49, from 1,085 verbal autopsies, according to specific cause

\begin{tabular}{lrr}
\hline Cause of death & Number & Percent \\
\hline Liver disease & 13 & 26.5 \\
Cardiac disease & 10 & 20.4 \\
Cerebrovascular accident (stroke) & 6 & 12.2 \\
Epilepsy & 3 & 6.1 \\
Brain tumor & 1 & 2.0 \\
Iatrogenic causes & 41 & 8.1 \\
Tuberculosis & 3 & 6.1 \\
Malaria & 2 & 4.0 \\
Hematological disorders & 2 & 4.0 \\
Renal failure & 2 & 4.0 \\
Pulmonary edema & 2 & 2.0 \\
Pulmonary embolism & 1 & 2.0 \\
Hematemisis & 1 & 2.0 \\
Total & 1 & 9.4 \\
\hline
\end{tabular}

${ }^{1}$ Three of these deaths were due to mismatched blood transfusions.

\section{DisCUSSION}

Revisiting the Pakistan Demographic and Health Survey 2006-07 analysis of verbal autopsies has provided information that was not captured in the initial analysis. Though the psychosocio-cultural factors that impact the lives of women in Pakistan and, in particular, their health and survival, are well known, this analysis underscores the magnitude of the issue. This together with deficiencies in the quality of care, especially emergency obstetric care, in hospitals reported in two studies ${ }^{3,4}$ are a matter of great concern and need to be addressed simultaneously.

An overwhelming majority of women whose verbal autopsies were revisited had no education. Among those who were educated, education emerges as an important positive factor. Neglect, ignorance and disenfranchisement decrease with higher levels of education and the supportive role of the family improves as education levels of women increase. This was shown to be especially true for women with middle education. It can be hypothesized that the families of the educated women were probably also educated and, therefore, their

${ }^{3}$ IR Siddiqui, T Rizvi, SN Jafarey. 1999. Situation analysis of emergency obstetric care (EOC) in four districts of Sindh. J Coll Physicians Surg Pak 9:187-9.

${ }^{4}$ FF Fikree, A Mir, IU Haq. 2006. She may reach a facility but still die! An analysis of quality of public sector maternal health services, District Multan, Pakistan. J Pak Med Assoc 56:156-63. 
health-seeking behaviors, individually and collectively, were much better. As far as superstition and spiritual / ritual treatment was concerned, however, education made no difference.

Employment of women for meager sums of money does not improve the financial condition of the family, at least not enough for her to seek and avail medical help.

In Pakistan, there is a growing concern about violence toward women, especially during pregnancy. ${ }^{5}$ The substantial number of cases identified as ambivalent is an indication of the gravity of domestic violence, which is disguised and presented as death due to disease or accident. This was true in our review when verbatim reports of others were compared against the reports of the respondents; this can only occur when there are "other" individuals who provided information that can be used for the purpose of comparing against the information provided by the primary respondents of the verbal autopsies. Being surrounded by her own blood relatives and living in the "safety" of her own house, within the confines of "chador and chardewari," does not mean that a woman is protected against violence.

Issues that have been traditionally seen as barriers are, indeed, real problems. For example, health facilities, especially in rural areas, either do not exist or, if they do, are perceived as centers where services are of poor quality and are, therefore, not accessed. The attitude of health care providers is also a barrier to accessing health care, and leads people to resort to alternative informal treatments. Psycho-socio-cultural and traditional barriers -- poverty, difficult terrain, weather conditions, poor/absent roads, unavailability of transport, absence of staff from the health facilities, unavailability of equipment or medicines -- all add to the miseries of women, and can lead to their death.

Superstition permeates the fabric of Pakistani society. Many believe that diseases are the result of being possessed by spirits, jins (demons), etc., and, because of this, they seek out faith healers as the appropriate people to "treat" such problems rather than seeking medical solutions. Myths and misconceptions associated with family planning, such as the fear and misconceptions regarding tubal ligation - for example, that tubal ligation will result in obesity or will bring bad luck and something bad happening to the existing children -prevents women from using contraceptives, resulting in unplanned and unwanted pregnancies and the resulting consequences. The fear of a husband remarrying because of

${ }^{5}$ F Fikree, SN Jafarey, R Korejo, A Afshan, JM Durocher. 2006. Intimate partner violence before and during pregnancy: experiences of postpartum women in Karachi, Pakistan. J Pak Med Assoc. 56:253-7. 
fertility concerns/issues is another psycho-social-cultural factor that puts women under pressure, in this case because of a felt need to demonstrate their fertility again and again, thereby increasing their family size without the family's resources taken into consideration.

A large number of women and their families are still seeking remedies for their life threatening illnesses from all kinds of quacks in the form of pirs, faqirs, moulvis and other similar "healers." This indicates that harmful traditional, cultural and religious beliefs are ingrained in the community and are negatively impacting healthseeking behaviors. The shrines seem to be centers for a variety of activities. Their function ranges from treatment of chronic physical and mental ailments to treating infertility and fixing a difficult mother-in-law or a rebellious daughter-in-law, etc. Women are sometimes left alone at these shrines. It does not take much imagination to understand how these women are treated; it seems that on a regular basis the media is reporting cases of abuse at these shrines. Circumstances that make women feel helpless and lead to severe stresses and strains in their lives were documented. For the women whose verbal autopsies were reviewed, these included a number of situations recounted in

\section{Hafiza*}

She was 22 years old, uneducated and engaged to be married. She lived in a huge house. She was alone one night as the family had gone visiting.

She lit up the tandoor (oven) with firewood and started cooking.. Strong winds resulted in sparks of fire catching her clothes. She started running and this further increased the strength of the flames and all her clothes caught fire. As she was alone, nobody could save her. Neighborhood children came running and found her ablaze. When the children called the women of the neighborhood they found her dead. They concluded that this was an accidental death.

A detailed account of Hafiza's final moments, when she was allegedly alone and was found burnt to death by neighbors, appears very suspicious.

$\overline{* \text { All names have been changed. }}$ the verbatim reports. Single young women living with their married brothers and their wives; forced marriages when no emotional support was available from her family, husband or inlaws; husband's remarriage or more than one wife living together when the husband discriminates between the wives; and delivery of a girl child were all events or situations where women were left to fend for themselves in a society that discriminates against them. In too many cases, the women had nowhere to turn for emotional support.

All 10 deaths identified as ambivalent were due to violence. In addition, among those where there was suspicion of ambivalence, a majority died in suspicious circumstances. They were young, single and educated. Being married appears to provide some protection. It is speculated that educated women are aware of their rights and get opportunities to go out of the house to meet, socialize, and make friends - these women and are then "silenced" if they 
make friends of their own choosing or want to marry a person they have chosen, or exercise their rights on other issues.

The issues highlighted in the verbatim reports include gender discrimination, marital disharmony, quarrels with husband and in-laws, forced engagement/marriage, broken engagement, love affair, extramarital affair leading to honor killing, infertility, quest for a son, the woman being sent to her parents after the birth of a girl child, etc.

Some of these deaths may have been due to homicide or suicide when the relatives had described it as an accident or a disease. Whether some of these deaths were due to complications of unsafe abortions was also extremely difficult to document, as this is a taboo topic associated with shame and even if a respondent knew this to be the case, they would probably not disclose it to the interviewer. Given the social and cultural stigma associated with the issue, the deceased woman might not even have disclosed the situation to her relatives. This is the experience of clinicians who see women in hospitals with complications of unsafe abortions. These unfortunate women and their accompanying relatives do not give the correct information and often refuse to accept that a pregnancy has been terminated. On their deathbeds these women refuse to disclose the identity of the abortion provider -- they, may well feel indebted to them for relieving them of an unwanted pregnancy.

Incidents reported as snake bites, electrocution by live wires of faulty washing machines, burns by accidently catching fire in the kitchen and accidental gun shots were viewed with suspicion. Deaths due to "faulty stoves" and resultant burns are well known in Pakistan. Women are burned to death deliberately over petty issues that include, among many other things, dowry-related problems, and these are attributed to bursting of stoves. Similarly, deaths of women are regularly reported in the press/media due to electrocution by "faulty washing machines" - could these be the same types of circumstances reported as "manufacturing defects" with gas stoves? One woman was said to be alone at home and was found burned to death, but an "eye witness" account of her final moments is described in great length. There were three deaths reported as having been caused by snake bites; however, there was no mention of anyone having seen the snake or marks of a snake bite on the woman

When the final events of these so-called accidental deaths were reviewed, it was felt that there were many loopholes in the stories narrated by the respondents. In some cases, the interviewers thought that information was being concealed. In such cases, the possibility of violence -- homicide or suicide -- was suspected.

Some late maternal deaths were due to iatrogenic causes, i.e., complications of surgery. This 
reflects the poor state of affairs of the health system that needs to be addressed by health professionals and policymakers. One way to address these kinds of deaths is to build the level of skills of health care providers and establish supervised and structured competency-based trainings at the undergraduate and postgraduate levels.

Late maternal deaths due to liver diseases were also identified. Liver disease was the leading cause of indirect maternal deaths, responsible for 26.5 percent of indirect maternal deaths. Hepatitis is of great public health importance in Pakistan and these findings bring to focus the need to create awareness about preventive aspects of hepatitis. Unpacking the indirect causes of maternal deaths reveals the significance of major issues for policy, e.g., hepatitis emerging as a major cause of maternal deaths -- though, in the case of hepatitis, it is known that there is high prevalence in communities. A national program for hepatitis prevention and control was launched in 2005 to reduce the prevalence, morbidity and mortality due to viral hepatitis, but a significant impact is yet to be seen.

Currently, blood banks are poorly organized in Pakistan, the services are either not available or, if present, quality standards are not followed. So men and women die either when blood transfusions are not given in time or suffer from the consequences of poor services when unsafe or mismatched blood is used for transfusions. These reactions can result in immediate deaths or be responsible for conditions that manifest themselves later, like hepatitis. The importance of organizing quality blood transfusion services cannot be said enough. A reliable quality blood supply plays a vital role in any health service delivery system. Too often, especially in peripheral areas, unscreened blood is transfused and this practice may be a factor in the spread of hepatitis. The fact that 6 percent of indirect maternal deaths due to indirect causes were due to blood transfusion reaction is alarming.

There is also a question of whether all blood transfusions are medically indicated. It is well known that blood transfusions are given to expedite the treatment process, e.g., treating chronic anemia, when no such haste is required and other alternative treatments are not given much thought.

There were cases revisited in which those analyzing the verbal autopsies and verbatim reports felt that if the deceased women had stayed home and not gone to the health facility they would probably be living today. For example, a multigravida who had gone to hospital for a checkup and was advised to have a Caesarean section due to a breech presentation (baby presenting with legs first) and died on the operating table or the cases of the three women who died of mismatched blood transfusions. 


\section{CONCLUSION}

Several factors contribute to deaths of women, including deaths during pregnancy and childbirth. In-depth analysis shows that psycho-socio-cultural factors pose a great threat and need to be addressed, along with other barriers, to save the lives of women in Pakistan. 



\section{ANNEX}

\section{A. Guidelines for Reviewers}

(Note: Form was slightly modified for this report.)

Pakistan Demographic and Health Survey 2006-07

Reviewer's Assignment to Identify Late Maternal death, Ambivalent Cases \& Cases appropriate for Case Study in Adult Female Deaths

Reviewer's Assignment to Unpack Psycho- Socio- Cultural factors resulting in Maternal Deaths

\section{Guidelines for Reviewers}

\section{Task for Reviewers:}

Review all forms to:

- Identify Late Maternal Deaths and if late maternal deaths then fill the Reviewer's form for "To unpack Psycho-Socio-Cultural factor resulting in Maternal Deaths"

- Identify Ambivalent Deaths (violence/ suspected abortion/ deaths in suspicious circumstances)

- Identify Deaths appropriate to be written as Case Studies

Review Maternal Death forms to:

Unpack the Psycho-Socio-Cultural factor resulting in Maternal Deaths

- Reclassify Indirect Maternal Deaths ignoring the ICD 10 classification

\section{Reviewer's Code:}

- Dr. Azra Ahsan A

- Dr. Shireen Bhutta B

- Dr. Sadiah Ahsan Pal C

- Dr. Farah Naz Raza D

\section{Definitions}

\section{Maternal Death:}

Maternal death is defined as "the death of a woman while pregnant or within 42 days of termination of pregnancy, irrespective of the duration and site of the pregnancy, from any cause related to or aggravated by the pregnancy or its management but not from accidental or incidental causes."

\{The Tenth Revision of the International Classification of Diseases (ICD-10)\} 


\section{Late Maternal Death:}

Late maternal death is defined as the "death of a woman from direct or indirect obstetric causes more than 42 days but less than one year after termination of pregnancy."

\{The Tenth Revision of the International Classification of Diseases (ICD-10)\}

\section{The Four Delays:}

1'st Delay:

$2^{\text {nd }}$ Delay:

3rd Delay:

$4^{\text {th }}$ Delay:
Delay in identifying a complication

Delay in making a decision to seek treatment

Delay in getting the woman to the health care center

Delay in receiving quality treatment

\section{Education Categories:}

Primary: Class 1-5

Middle: $\quad$ Class 6-8

Secondary: Class 9-10

- Higher: Class 11 or more

\section{Source of Drinking Water:}

- Improved Source:

Piped into dwelling/yard/plot (piped)

Public tap/ standpipe (piped)

Tube well/ borehole/ hand pump

Protected dug well

Protected spring/ karez

Rain water

Bottled water

- Non- Improved Source:

Unprotected dug well

Unprotected spring

Tanker truck/ cart with tank

Surface water

\section{House Hold Characteristics:}

- Pacca: When floor, wall and the roof is "finished"

- Semi Pacca: When one or two of the three (floor, wall or roof) is "finished"

- Kaccha: When floor, wall and roof is "not finished"

\section{Birth Preparedness:}

(Some information may be available in verbatim)

1. Selection of a skilled birth attendant (SBA) and place of delivery

Procurement of essential items for delivery e.g., clean delivery kit, things needed for the mother and baby

Knowledge of danger signs for mother and newborn

Knowledge of where and to whom to go for medical help

Access to funds and means for emergency transportation

Identification of blood donors 


\section{Criteria for appropriate Case Study:}

- Ambivalent Deaths (violence/ suspected abortion/ deaths in suspicious circumstances)

\section{Name:}

Cluster Number:

Household Number:

Reviewer:

\author{
[Name] \\ [Number] \\ 037 \\ Dr Azra Ahsan
}

\section{Sample Case Study}

[Name] a 44 years old woman, resident of [area] in [village] in Sindh, was pregnant for the $17^{\text {th }}$ time. She had 14 children and 2 miscarriages. 13 of these children were alive, 6 boys and 7 girls. She was uneducated and helped her husband in making earthenware pots. The husband was 12 years her senior, had primary education and worked as a potter and a peasant. They lived in a single room house made of mud.

This was an unwanted pregnancy and was not using any family planning method. She tried to terminate this pregnancy in the fifth month by taking medicines from the dai. She never went for an antenatal check up as she thought it costs too much, was too far, there was no transport and long waiting time in the hospital.

In the $8^{\text {th }}$ month of her pregnancy she started to bleed and after 2 days went to see a "doctor", who advised her to see a lady doctor and blood transfusion.

They could not go to the hospital for the next 15 days as it was raining heavily, so much that the banks of canals were broken and people were commuting in small boats. They also did not have enough money and were heavily indebted to the zamindar, who refused to lend anymore money. The husband finally managed to borrow some money and took her to civil Hospital, in [location]. It was a Sunday and no doctor was present in the hospital. The nurse on duty said that [name] was too ill, severely anemic and required 7-8 pints of blood. So she advised to take the patient "somewhere else." The family members' blood group did not match the woman and requested they be given blood now and will replace it later. The woman stayed in the hospital for 8 hours, was given an IV infusion on family's insistence, but was not admitted. She died undelivered in the hospital or on the way to the next hospital.

They spent 4000 Rs for treatment, which they had managed to borrow from the zamindar.

The main respondent was a niece, who was pregnant and according to the interviewer looked very anemic, weak and unwell and not had any antenatal check up.

Hospital's reason for cause of death was blood loss, anemia and weakness; whereas, the family's perception of cause of death was anemia, weakness, poverty and rains.

\section{Comments:}

No lesson was learnt by the family

Husband and wife have the same profession and like all the other unpaid household chores, she contributes to his work but does not get wages

The husband is much older than her

She died but the relatives thought her condition was somewhat serious but not severe enough to die She had night blindness

The family's expectation that blood can be arranged by the hospital in any quantity at a short notice No blood bank or a list of voluntary blood donors

The HCP's assessment of cause death is mainly medical, whereas the family's assessment is more inclusive and social cultural issues are taken into consideration. Their assessment of medical reasons is also accurate 


\section{B. Reviewer's Form: Case Study Form}

\section{Pakistan Demographic and Health Survey 2006-07 Case Study}

CLUSTER NUMBER:

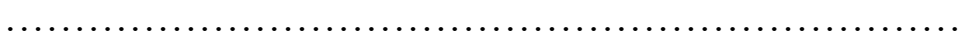

$\cdots$

HOUSEHOLD NUMBER:

NAME OF DECEASED WOMAN:

REVIEWER'S NAME AND CODE:

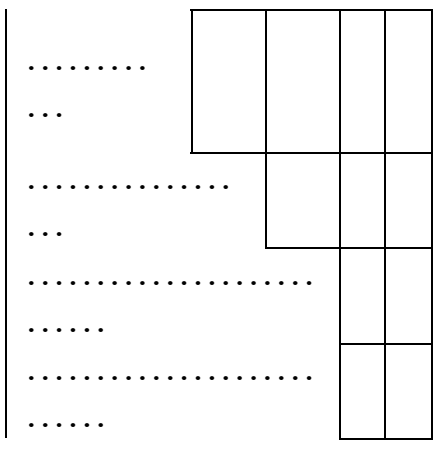




\section{Reviewer's Form: Themes Form for Maternal/Adult Female Deaths}

(Note: Form was slightly modified for this report.)

Pakistan Demographic and Health Survey 2006-07

Themes Form for Maternal/Adult Female Deaths

\section{Cluster number \\ Household number \\ Name of the deceased woman \\ Age}

Educational Status

Employment Status

Marital Status

Gravida

Para

Reviewer's Name

\section{Themes}

Maternal / Female Death

Main Respondent

Existing Risk Factor

Poverty

Neglect/ Non-Supportive Family

Supportive Family

Domestic Violence

Helplessness/ Low self esteem

Ignorance

Disenfranchisement (Availability \&

Accessibility) of health services

Spiritual/ritual Treatment

Superstition

Comments

Other Themes (if any)

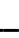

(years)

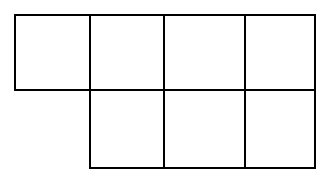

\begin{tabular}{|c|c|c|c|c|c|}
\hline $\begin{array}{c}\text { No } \\
\text { education }\end{array}$ & Primary & Middle & \multicolumn{2}{|c|}{ Secondary } & Others \\
\hline \multicolumn{3}{|c|}{ Employed } & \multicolumn{3}{|c|}{ Unemployed } \\
\hline Married & \multicolumn{2}{|c|}{ Divorced } & Widowed & Separated & $\begin{array}{c}\text { Never } \\
\text { Married }\end{array}$ \\
\hline
\end{tabular}




\section{Reviewer's Form: Unpacking Psycho-Socio-Cultural Factors and Identifying Late Maternal Death, Ambivalent Cases \& Cases Appropriate for Case Study Resulting in Non-maternal Deaths}

(Note: Form was slightly modified for this report.)

Pakistan Demographic and Health Survey 2006-07

REVIEWER'S ASSIGNMENT TO UNPACK PSYCHO-SOCIO-CULTURAL FACTORS AND IDENTIFY LATE MATERNAL DEATH, AMBIVALENT CASES \& CASES APPROPRIATE FOR CASE STUDY RESULTING IN NON MATERNAL DEATHS






\section{E. Reviewer's Form: Unpacking Psycho-Socio-Cultural Factors and Identify Ambivalent and Interesting Cases Resulting in Maternal Deaths}

(Note: Form was slightly modified for this report.)

Pakistan Demographic and Health Survey 2006-07 REVIEWER'S ASSIGNMENT TO UNPACK PSYCHO-SOCIO- CULTRUAL FACTORS AND IDENTIFY AMBIVALENT AND INTERESTING CASES RESULTING IN MATERNAL DEATHS

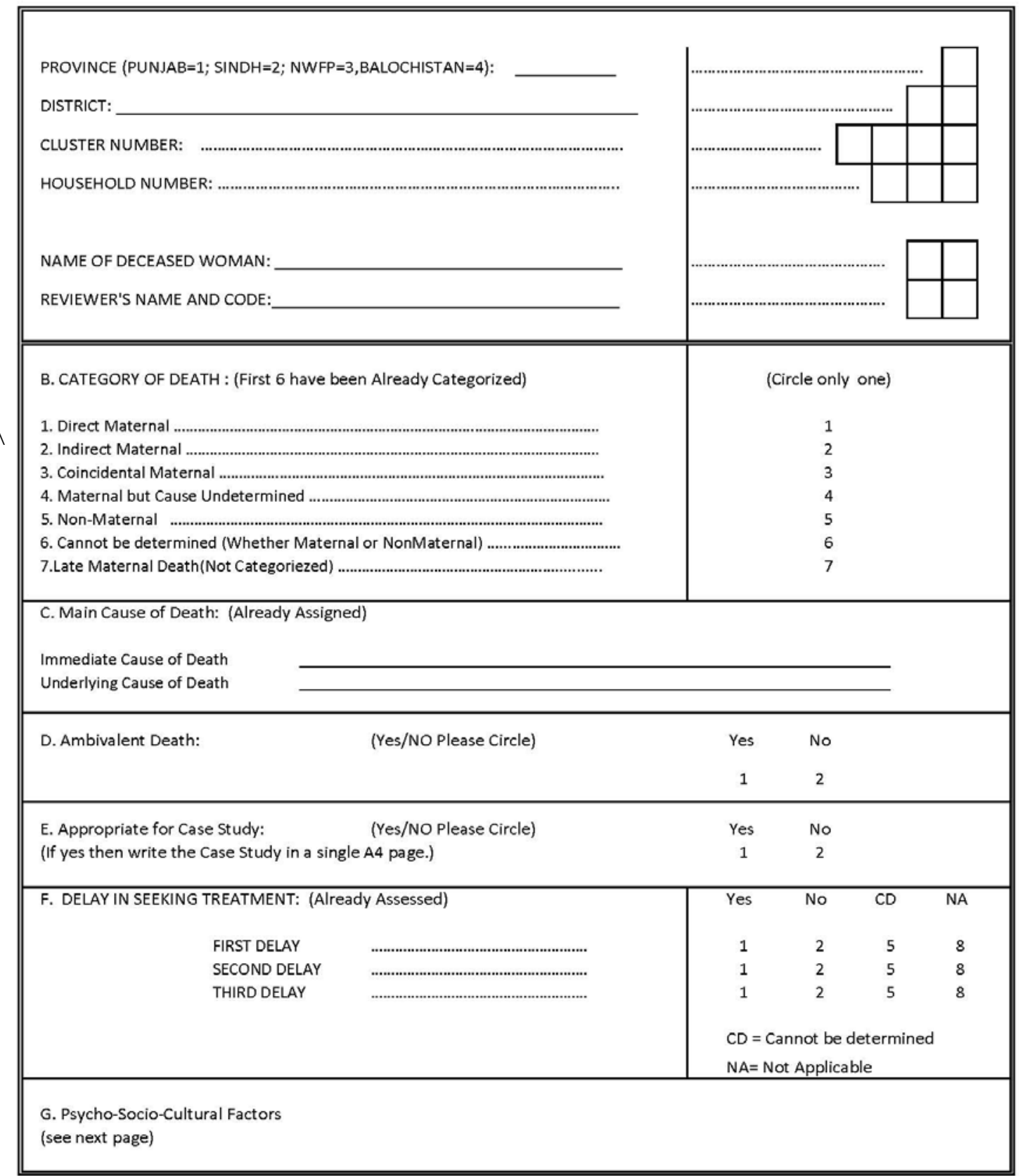

